\title{
Analysis of heavy metals in roadside soils and crops along the Obansandjo way in the Accra metropolis
}

\author{
J. K. BENTUM *, D. K. ESSUMANG, J.K. TUFFUOR and I. AGYAKUM \\ Environmental Research Group, Department of Chemistry, University of Cape Coast, Cape Coast. Ghana. \\ ${ }^{*}$ Corresponding author, E-mail: johnbentum@yahoo.com
}

\begin{abstract}
This paper discusses the levels of some heavy metals $(\mathrm{Ni}, \mathrm{Cu}, \mathrm{Pb}$ and $\mathrm{Zn})$ in roadside soils and crops along the Obansandjo way in the Accra metropolis of Ghana. Soil and plant samples were collected from three different sites; Kawukudi (K), Ebony (E), and Dzorwulu (D) all along the Obansandjo way in Accra. The samples taken were preserved and later acid digested and analyzed along side control soil and plant samples using standard analytical methods. The following mean levels of $\mathrm{Ni}, \mathrm{Zn}, \mathrm{Cu}$ and $\mathrm{Pb}$ on the roadsides were detected: $228.65 \pm 102.98,35.98 \pm 18.39,24.577 \pm 9.04$ and $18.25 \pm 13.05$ (all in $\mathrm{mg} / \mathrm{kg}$ ) respectively. The mean level of $\mathrm{Ni}$ was above the critical permissible concentration. $\mathrm{Ni}, \mathrm{Zn}, \mathrm{Cu}$ and $\mathrm{Pb}$ in the crops were: $3.343 \pm$ 2.0, $6.97 \pm 4.5,1.909 \pm 0.71$ and $3.515 \pm 1.3$ (all in $\mathrm{mg} / \mathrm{kg}$ ) respectively. $\mathrm{Ni}, \mathrm{Pb}, \mathrm{Cu}$ and $\mathrm{Zn}$ were detected in both soils and crops. The levels of all the metals except $\mathrm{Ni}$ were below the phototoxic levels.

(C) 2010 International Formulae Group. All rights reserved.
\end{abstract}

Keywords: Obansandjo way, heavy metals, roadside soils and plants.

\section{INTRODUCTION}

The presence of heavy metals in soils and crops grown along roadsides in urban communities is of concern because of the hazards caused by heavy metals. According to Garcia and Millan (1988), Sithole et al. (1993) and Fatoki (1996), heavy metal pollution of roadside soils and crops grown along road verges are largely due to releases from automobiles.

Chow (1970) has observed that proximity to road with high traffic density may contribute substantially levels of these metals in the soil. Lead for example has been found in the top $5 \mathrm{~cm}$ of soil at a level of 403 $\mathrm{mg} / \mathrm{kg}$. Studies have shown that vegetation in contaminated soils may absorb high concentrations of heavy metals which are potentially toxic to crops, animals and humans (Okoronkow, 2005).

Urban agriculture has been practiced in Accra for over two decades; but with the increasing lack of access to land, due to infrastructure development and high rate of urbanization accompanying the ensuing rapid growth of unemployment, cultivation of food crops along road verges, banks of drainage channels and other unsuitable areas has become increasingly common. With increasing traffic density in Accra, heavy metal pollution of soils and vegetation along the roadside due to releases from automobile is probable and therefore warrants investigation. The study seeks to investigate the levels of some heavy metals, $\mathrm{Pb}, \mathrm{Zn}, \mathrm{Cu}$ and $\mathrm{Ni}$ contamination in some soils and food crops grown along the Obasandjo way in the 
Accra metropolis of Ghana, as a basis for future monitoring of the impact of the automobile releases on soils and crops along that roadside, and to ascertain if the levels of the metals are above recommended levels.

\section{MATERIALS AND METHODS Sampling}

The selected sites at Kawukudi, Ebony and Dzorwulu, are all settlements along the Obasandjo way at Accra. The sites were chosen because of the variable traffic densities in those areas, the cultivation of crops along the sides of the roads and the proximity of the selected soils and crops to heavy metal pollution. Samples were collected in the dry season, between November and December 2007, when the soils contain relatively lower moisture, since heavy metals adhere to the soil when the water content in low.

Soils and plants samples, including control samples were collected from preselected sites or farms close to the sides of the Obasandjo road at Kawukudi, Ebony and Dzorwulu, urban communities. Each sample site was divided into four areas before sampling. Ten samples of soils were collected at random at a depth of $0-10 \mathrm{~cm}$, from each of the demarcated areas using a garden trowel into a plastic container, mixed to obtain a homogenous sample and then placed into a labeled plastic polyethylene bags for laboratory analysis. Four sets of samples were obtained for each of the three pre-selected sites.

Plant samples were collected using a pair of scissor and placed into labeled plastic bags for laboratory analysis. Control samples of soils and plants were collected at a distance of 50-70 $\mathrm{m}$ from the road.

\section{Sample treatment}

\section{pH and moisture content determination}

The $\mathrm{pH}$ and the moisture content of the soils were determined using standard methods (David, 1994).

The soil samples were air-dried and passed through $2 \mathrm{~mm}$ mesh. $1 \mathrm{~g}$ of each of the homogenized samples of soils was put into a $100 \mathrm{ml}$ beaker and digested using the method described by MAFF (1981). The plant samples were first dried in the sun, and in the oven at $105{ }^{\circ} \mathrm{C}$. The samples were milled after drying and $2 \mathrm{~g}$ placed into a $50 \mathrm{ml}$ flask. The sample was digested using $1 \mathrm{ml}$ of $(5: 1: 1)$ $60 \%$ perchloric: sulphuric: nitric acids mixture and finally diluted to $50 \mathrm{ml}$ (Allen et al., 1979). Blank solutions were also prepared for the soil and plant samples. All the digests and the blank solutions were analyzed for $\mathrm{Pb}, \mathrm{Cu}$, $\mathrm{Zn}$ and $\mathrm{Ni}$ with an ICP atomic absorption spectrometer 112S INTEPID model. All analyses were carried out in duplicate.

\section{Reproducibility studies}

In order to validate the precision of the analysis, reproducibility studies were carried out by analyzing double distilled water containing 2, 5 and $10 \mathrm{ppm}$ of $\mathrm{Pb}, \mathrm{Zn}, \mathrm{Cu}$ and Ni. Three replicate analyses were carried out.

\section{RESULTS AND DISCUSSION}

The mean percentage recoveries of the double distilled water were; $\mathrm{Pb}, 95.7 \pm 0.46$ $100.1 \pm 0.40 ; \mathrm{Zn}, 96.1 \pm 0.72-99.56 \pm 2.4 ; \mathrm{Cu}$, $96.6 \pm 0.15-100.9 \pm 0.1$ and $\mathrm{Ni}, 97.1 \pm 0.53-$ $98.4 \pm 0.35$. The moisture content and $\mathrm{pH}$ of the soils are shown in Table 1. The results of the metal analysis have been shown in Figures 1-3. The overall mean (mean \pm RDS) distribution of $\mathrm{Pb}, \mathrm{Cu}, \mathrm{Zn}$ and $\mathrm{Ni}$ in the soils were $18.25 \pm 13.045,24.577 \pm 9.04$, and $35.964 \pm 18.39$ and $228.648 \pm 102.98 \mathrm{mg} / \mathrm{kg}$ respectively. The ranges of the metal concentration in the soils were $\mathrm{Pb}, 2.52-52.39$ $\mathrm{mg} / \mathrm{kg}$; Cu, 2.43- $143.0 \mathrm{mg} / \mathrm{kg}$; Zn 7.967$63.43 \mathrm{mg} / \mathrm{kg}$ and $\mathrm{Ni}, 47.98-421.2 \mathrm{mg} / \mathrm{kg}$. Ni had the highest concentration and $\mathrm{Pb}$ the least. The levels of metals in the crops were much lower than those in the soils. The mean and ranges of the metals in the crops were respectively; $\mathrm{Pb}, 3.515 \pm 1.3$ and $1.12-5.856$ $\mathrm{mg} / \mathrm{kg} ; \mathrm{Cu} \quad 1.907 \pm 0.71$ and $1.189 \quad-3.262$ $\mathrm{mg} / \mathrm{kg} ; \mathrm{Zn} \quad 6.97 \pm 4.5$ and $2.636-16.142$ $\mathrm{mg} / \mathrm{kg}$; and $\mathrm{Ni} 4.611 \pm 2.0$ and $0.155-5.089$ $\mathrm{mg} / \mathrm{kg}$. Zn had the highest concentration in the 
crops and $\mathrm{Cu}$ the least. The overall mean levels of the heavy metals in the soils and crops at the three sites are shown in, Figures 1 and 6 respectively. The mean levels of the metals in the soils was in the order $\mathrm{Pb}<\mathrm{Cu}<$ $\mathrm{Zn}<\mathrm{Ni}$ whereas in the crops the order was, $\mathrm{Cu}<\mathrm{Ni}<\mathrm{Pb}<\mathrm{Zn}$ (Figure 3).
Figures 2 to 4 show the mean concentrations and the trends in the distribution of the metals in soils and crops at the three sites. Generally the trend in the distribution of the heavy metals in the roadside soils at Kawukudi, Dzorwulu and Ebony were similar with considerably variations in the metal levels (Figure 2).

Table 1: Mean moisture contents of soils.

\begin{tabular}{ll}
\hline Sampling site & Percent moisture (Mean \pm SD) \\
\hline Ebony & $1.46 \pm 0.44$ \\
\hline Kawukudi, & $0.565 \pm 0.102$ \\
\hline Dzorwulu & $1.39 \pm 0.209$ \\
\hline
\end{tabular}

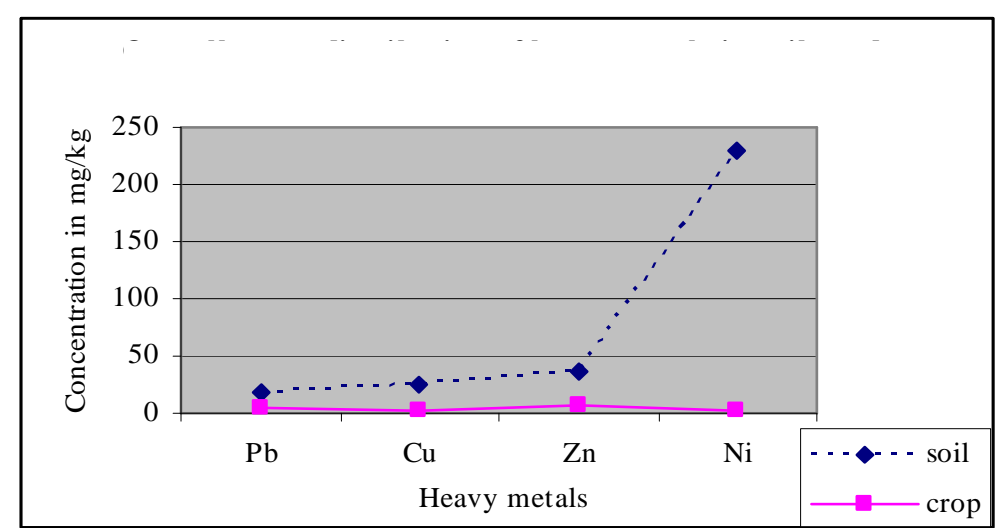

Figure 1: Overall mean levels of heavy metals in roadside soils and crops.

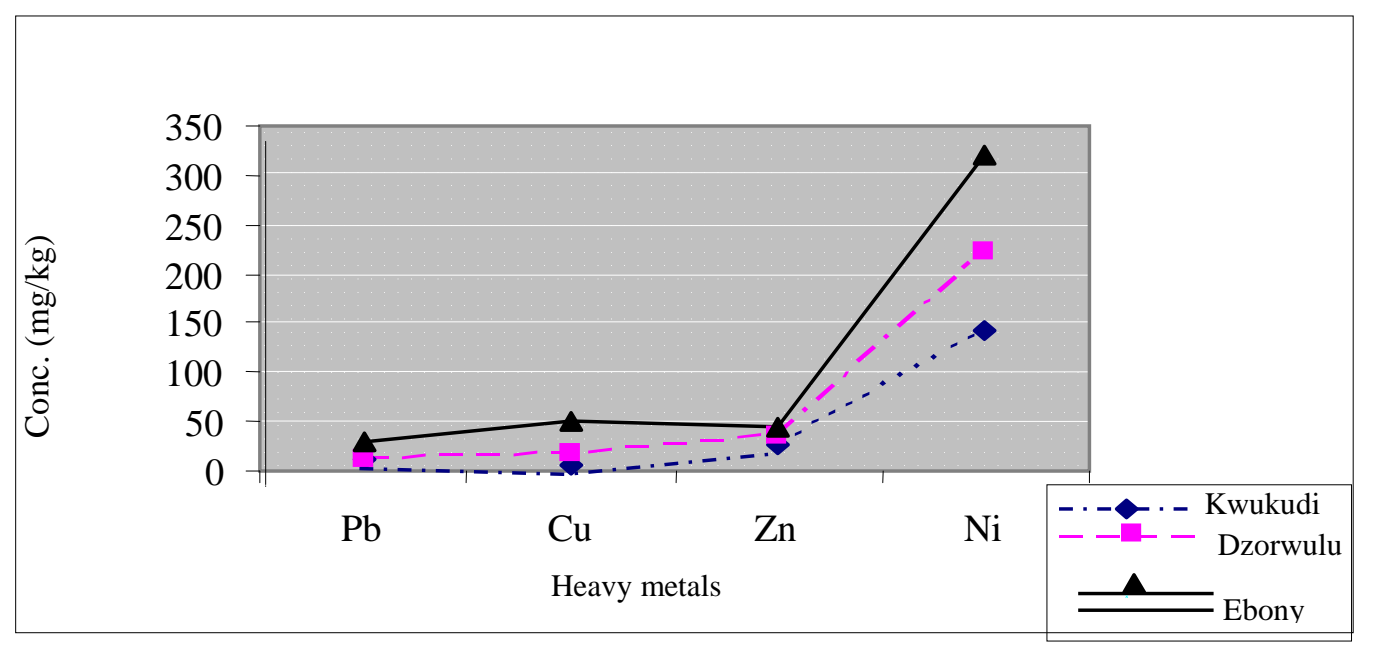

Figure 2: Mean levels of heavy metals in roadside soils at Kawukudi, at Dzorwulu and Ebony. Conc. = Concentration. 


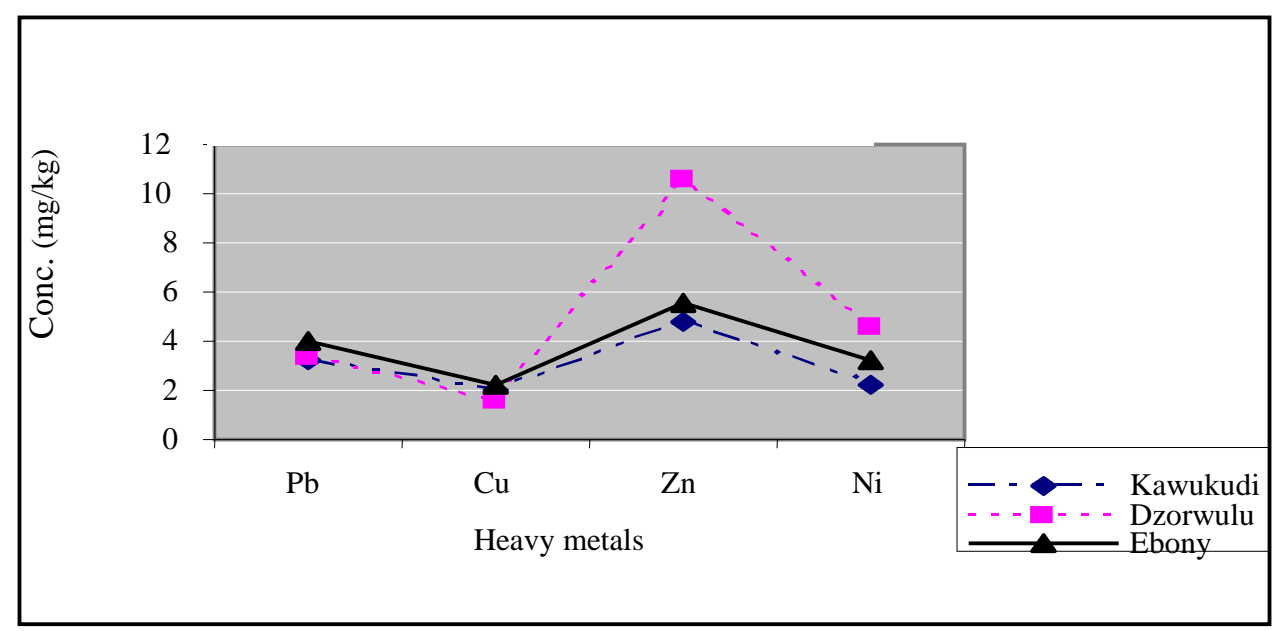

Figure 3: Mean levels of heavy metals in roadside crops at Kawukudi, Dzorwulu and Ebony.

The distribution showed that at all the three sites $\mathrm{Ni}$ had the highest concentration in all the soils (Figure 2). Also Ebony had the highest levels for all the metals. The trends in the distribution of the metals at the sites were: Kawukudi, $\mathrm{Ni}>\mathrm{Zn}>\mathrm{Pb}>\mathrm{Cu}$; Dzorwulu, $\mathrm{Ni}$ $>\mathrm{Zn}>\mathrm{Cu}>\mathrm{Pb}$ and Ebony, $\mathrm{Ni}>\mathrm{Cu}>\mathrm{Zn}>\mathrm{Pb}$. The distributions of these metals in the crops at all the three sites were also similar (Figure 3 ), with $\mathrm{Zn}$ having the highest overall mean concentration $(6.97 \pm 4.5 \mathrm{mg} / \mathrm{kg})$ and $\mathrm{Cu}$ the least $(1.909 \pm 0.71 \mathrm{mg} / \mathrm{kg})$. $\mathrm{Ni}$ and $\mathrm{Pb}$ were variable. The trends in the distribution of the metals in the crops were: Kawukudi, $\mathrm{Zn}>\mathrm{Pb}$ $>\mathrm{Ni}>\mathrm{Cu}$; Dzorwulu, $\mathrm{Zn}>\mathrm{Ni}>\mathrm{Pb}>\mathrm{Cu}$ and Ebony, $\mathrm{Zn}>\mathrm{Pb}>\mathrm{Ni}>\mathrm{Cu}$.

The results suggest that there has been heavy metal enrichment of roadside soils and crops close to the Obansandjo way. The results could not be related to previous findings since there are no records of previous findings. The distributions of the metal in all the sites follow a similar trend as shown in Figure 2. There were large variations in the levels of the individual metals in the soils compared to the crops. The variations observed in the levels of the metals in both the roadside soils and crops are not strange. Studies have revealed that the amount of metal adsorbed by the soils and uptake by plants along roadsides depends on traffic density and the proximity to the sources of release from the roadside soils and vegetation (Rodriguez-Flores et al., 1982; Sithole et al., 1993). The levels of the $\mathrm{Pb}, \mathrm{Cu}$ and $\mathrm{Zn}$ in the soils and vegetables were comparable to levels of metals in roadside soils and vegetables in Jordan (Jaradat et al., 1999).

However the observed levels in the soils were lower than levels found in some roadside soils in Auckland (Ward et al., 1977), and Nigeria (Ndiokwere, 1984). The levels of $\mathrm{Pb}$ and $\mathrm{Zn}$ in the vegetables analyzed were between those found in vegetables in Kampala (Nabulo, 2004) The samples collected at Ebony had the highest metal concentration probably because of its closeness to the road, about 5-10 $\mathrm{m}$ and the very high volume of traffic compared to the other sites, which were further away from the road, $20-40 \mathrm{~m}$, and also the nearness of the site at Ebony to an automobile mechanical shop. The exceptionally high levels of $\mathrm{Cu}$ in some of the soils particularly $\mathrm{E}_{2}$ and $\mathrm{D}_{2}$ which were 143 and $42.44 \mathrm{mg} / \mathrm{kg}$, respectively, could be due to the application of fungicides 'cocide 101'. Also, those two samples had higher levels of $\mathrm{Zn}$, above $60 \mathrm{mg} / \mathrm{kg}$. Even though the mean levels of all the metals were below recommended levels (ICRCL, 1987), 
$\mathrm{Ni}$ in samples $\mathrm{E}_{2}$ and $\mathrm{D}_{2}$ were within the tolerable level of $90-300 \mathrm{mg} / \mathrm{kg}$ recommended by Kabata Pendias and Pendias (1984). The mean nickel level in the soils was above the critical permissible concentration of $50 \mathrm{mg} / \mathrm{kg}$ as given by MAFF (1992). Copper levels were within the normal range of $2-250 \mathrm{mg} / \mathrm{kg}$ (Kabata Pendias and Pendias, 1984) and also below $300 \mathrm{mg} / \mathrm{kg}$ recommended by MAFF (1992). Generally the zinc levels were found to be above the normal range of $10-30 \mathrm{mg} / \mathrm{kg}$ observed by Logan (2000) and below the 100 $\mathrm{mg} / \mathrm{kg}$ as given by MAFF (1992). The levels of the metals in the crops were below the phototoxic levels of $30-300 \mathrm{mg} / \mathrm{kg}$ for $\mathrm{Pb} ; \mathrm{Zn}$, $100-400 \mathrm{mg} / \mathrm{kg}$ and $\mathrm{Cu}, \quad 20-100 \mathrm{mg} / \mathrm{kg}$ recommended by Alloway (1995). The levels of the $\mathrm{Ni}$ and $\mathrm{Pb}$ were within the ranges, 0.02$5.0 \mathrm{mg} / \mathrm{kg}$ for $\mathrm{Ni}$ and $5.0-10.0 \mathrm{mg} / \mathrm{kg}$ for $\mathrm{Pb}$. Thus the levels of the metals in the crops are not enough to cause harm to the crops. With the exception of $\mathrm{Ni}$, the concentrations of the other metals were far below the recommended dietary levels of the metals in foods by the United Kingdom Department of Health and the US (Ysart et al., 1999).

Generally the moisture content correlated positively with the concentration of metals in the crops, but the correlations were very weak $(\mathrm{P}<0.05)$.

\section{Conclusions}

Nickel, $\mathrm{Pb}, \mathrm{Cu}$ and $\mathrm{Zn}$ were detected in both soils and crops. The results suggest that heavy metal pollution of roadside soils and crops are largely due to releases from automobiles. The levels of all the metals except $\mathrm{Ni}$ were below the phototoxic levels and also lower than the recommended daily intake. Although the concentrations of the metals were below their recommended daily intake, their presences in the food samples analyze could lead to bioaccumulation in the body of consumers and pose health risk in future. The data obtained in this study could serve as a basis for further monitoring.

\section{ACKNOWLEDGEMENTS}

We wish to thank all the farmers for their support during the collection of samples. We are also grateful to the Tema Oil Refinery (TOR) for their technical support.

\section{REFERENCES}

Allen SE, Grimshaw HM, Parkinson JA, Quariby C, Rebort JO. 1979. Chemical analysis. In Methods in Plant Ecology SB Champan (2nd edn). Black Well Science Publishers: Oxford; 411- 426.

Alloway BJ. 1995. Heavy Metals in Soils. In Chemical principles of Environmental Pollution (2nd edn). Blackie and Son; 158-246.

Chow TJ, Earl JL. 1970. Science, 169(557): 13-9.

David RL. 1994. Soil Science: Methods and Applications. John Willy \& Sons: New York; 140-146.

Fatoki OS. 1996. Trace Zinc and Copper Concentrations in roadside surface soils and vegetation. A measurement of Local atmospheric pollution in Alice, South Africa. Environ. Intern., 22: 759-762.

Garcia R, Millan E. 1998. Assessment of Cd, $\mathrm{Pb}$ and $\mathrm{Zn}$ contamination in roadside soils and grasses from Gipuzkoa (Spain). Chemosphere, 37: 1615-1625.

Grace Nabulo, 2004. Assessment of Heavy Metal Contamination of Food Crops and vegetables from Motto vehicle Emissions in Kampala City, Uganda. A Technical Report submitted to IDRC-AGROPOLIS.

ICRCL (Interdepartmental Committee for the Redevelopment of Contaminated Land). 1987. Guidance on the Assessment and Redevelopment of Contaminated Land. Paper 59/83 2nd Ed. Department of the Environment, London.

Kabata-Pendias A, Pendias H. 1984. Trace elements in soils and plants. CRC Press Boca Raton Fla., 85: 107 - 129.

Jaradat QM, Kamal A, Moman KM. 1999. Contamination of roadside soil, plants and air with heavy metals in Jordan, a 
comparative study. Turk. J. Chem., 23: 209-220.

MAFF (Ministry of Agriculture, Fisheries and Food and Welch Office Agriculture Department). 1992. Code of Good Agriculture Practice for the Protection of Soil. Draft Consultation Document, MAFF, London.

Ndiokwere CI. 1984. A study of heavy metal pollution from motor vehicle emission and its effect on road side soil vegetation and crop in Nigeria. Environ. Pollut. Series, 8(7): 35 - 42.

Rodriguez-Flores M, Rodriguez-Castellon E. 1982. Lead and Cadmium levels in soil and plants near highways and their correlation with traffic density. Environmental Pollution (series B) 4: 281-290.
Sithole SD, Moyo N, Machekam M. 1993. An assement of lead pollution from vehicle emissions along selected roadways in Harare, Zimbabwe. Intern. J. Environ. Anal. Chem., 53: 1-12.

Ward N, Brooks RR, Roberts E, Boswell CP. 1977. Heavy metal pollution from automotive and its effects on roadside soil and pasture species in New Zealand Environ. Sci. Thecono., 2: 917-920.

Ysart G, Miller P, Crews H, Robb P, Baxter M, De L'Argy C, Lofthouse S, Sargent C, Harrison N. 1999. Dietary exposure estimates of 30 elements from the UK Total Diet Study. Food Additives and Contaminants, 16(9): 391 - 403. 